\title{
Sikap terhadap bantuan psikologis (tatap muka dan daring) ditinjau dari penyembunyian diri, harapan pengungkapan, dan stigma diri pada mahasiswa
}

Diany Ufieta Syafitri ${ }^{\prime *}$, Luh Putu Shanti Kusumaningsih ${ }^{2}$

${ }^{1,2}$ Fakultas Psikologi, Universitas Islam Sultan Agung, Indonesia

\begin{tabular}{l}
\hline Info Artikel \\
\hline Sejarah Artikel: \\
Diterima \\
04 November 2020 \\
Direview \\
04 Desember 2020 \\
Disetujui \\
II Januari 202 I \\
Dipublikasikan \\
I5 Januari 202I \\
\hline Keywords: \\
College students, \\
disclosure expectation, \\
mental health, \\
psychological help, \\
self-concealment, \\
self-stigma
\end{tabular}

\begin{abstract}
Abstrak
Objektif: Penelitian secara konsisten menunjukkan masyarakat di Asia memiliki sikap terhadap pencarian bantuan psikologis yang lebih buruk dibandingkan masyarakat di Amerika Serikat atau Eropa. Tujuan penelitian ini adalah untuk mengetahui apakah penyembunyian diri, harapan pengungkapan, dan stigma diri mampu menjadi prediktor bagi sikap terhadap bantuan psikologis

Metode: Penelitian ini menggunakan metode survei kuantitatif pada mahasiswa sejumlah 756 orang yang dipilih melalui cluster sampling. Instrumen pengumpulan data berupa Skala Penyembunyian Diri, Skala Harapan Pengungkapan, Stigma Diri, dan Skala Sikap terhadap Bantuan Psikologis Tatap Muka dan Daring. Analisis data yang digunakan adalah regresi linear berganda.

Temuan: Secara bersama-sama ketiga variabel memprediksi sikap terhadap pencarian bantuan psikologis daring $(\mathrm{F}=\mathrm{II}, 4, \mathrm{P}<.00 \mathrm{I})$ dan tatap muka $(\mathrm{F}=40,7$, $\mathrm{P}<.00 \mathrm{I}$ ) secara sangat signifikan, di mana harapan pengungkapan menjadi prediktor terkuat di antara prediktor lainnya dan ketiga prediktor ini lebih mampu menjelaskan sikap terhadap pencarian bantuan tatap muka daripada daring.

Kesimpulan: Penyembunyian diri, harapan pengungkapan, dan stigma diri mampu secara signifikan memprediksi sikap terhadap bantuan psikologis pada mahasiswa.
\end{abstract}

\footnotetext{
Attitudes toward psychological help (face-to-face and online) in terms of self-concealment, disclosure expectations, and selfstigma among students

Objectives: Research consistently shows that people in Asia have a worse attitude toward seeking psychological help than people in the United States or Europe. The purpose of this study was to determine whether self-concealment, disclosure expectations, and self-stigma could predict attitudes toward psychological help.

Method: The method employed in this study is a quantitative survey among 756 college students that was collected through cluster sampling. The instruments used were Self Concealment Scale, Disclosure Expectancy Scale, Self-Stigma of Seeking Help Scale, and Attitude Towards Seeking Psychological Help (offline and online) Scale. The data was analyzed with linear regression.

Findings: These three variables predicted very significant attitude towards seeking help online $(F=\mid I, 4, p<.00 I)$ and face to face $(F=40,7, p<.00 I)$, where the disclosure expectation became the strongest predictor among other predictors and these three predictors were better explained attitude towards seeking help face to face rather than online.

Conclusions: self-concealment, disclosure expectations and self stigma significantly predict attitude towards seeking psychological help
}

\footnotetext{
*Alamat korespondensi:

[Jl. Kaligawe Raya km 4, Genuk, Semarang]

[dianysyafitri@unissula.ac.id]
} 


\section{Pendahuluan}

Masalah kesehatan mental di Indonesia semakin menarik perhatian masyarakat. Hal ini ditandai dengan banyaknya permasalahan terkait kesehatan mental baik dalam berbagai konteks dan situasi. Namun sayangnya, masyarakat Indonesia masih dinilai rendah dalam literasi kesehatan mental. Rendahnya literasi kesehatan mental ini membuat masyarakat secara umum enggan mencari atau menunda mendapatkan bantuan psikologis profesional yang berdampak pada gangguan kesehatan mental yang tidak tertangani dan buruknya prognosis baik secara klinis maupun sosial dan ekonomi pada penderita (Bonabi dkk., 2016; Johnson \& Coles, 20I3). Hasil penelitian secara konsisten menunjukkan bahwa orang Asia, Afrika, dan Amerika Latin memiliki sikap yang kurang positif terhadap pencarian bantuan psikologis dibandingkan orang Eropa dan Amerika Serikat, sehinggalebih jarang menggunakan layanan psikologis yang tesedia (Chu dkk., 20 I I; Griffith dkk., 20 I I).

Perilaku pencarian bantuan ini juga dipengaruhi oleh berbagai faktor, salah satunya adalah ketidaktahuan di mana bisa menemukan bantuan psikologis. Hasil penelitian Syafitri \& Wijayanti (2017) menunjukkan bahwa lebih dari 50\% responden menyatakan bahwa mereka akan menemui psikolog atau psikiater saat mengalami masalah psikologis, tetapi sebesar 34\% dari responden tidak tahu di mana bisa mendapatkan bantuan psikologis dan $28 \%$ menyatakan tidak ada bantuan psikologis di sekitar mereka. Layanan psikolog puskesmas di wilayah Sleman dan Kota Yogyakarta telah ada sejak tahun 2004 dan 2010 , namun demikian, berdasarkan hasil penelitian Novianty \& Retnowati (20I6), layanan psikologi tersebut tidak serta merta dapat diterima oleh masyarakat maupun profesi medis lainnya. Masih banyak masyarakat yang tidak memahami peran psikolog dan memiliki stigma negatif terhadap layanan psikologi, yang berdampak pada rendahnya kunjungan pasien ke poli psikologi puskesmas.

Selain literasi kesehatan mental yang rendah, hasil penelitian Syafitri (20I8) yang dilakukan secara kualitatif terkait dengan perilaku pencarian bantuan psikologis pada mahasiswa di Semarang menunjukkan bahwa sebagian besar responden cenderung enggan untuk mendapatkan bantuan psikologis karena kecenderungan untuk menutupi permasalahan yang dihadapi (penyembunyian diri) dan hanya akan mencari bantuan psikologis saat permasalahan dinilai berat (harapan pengungkapan). Berdasarkan gambaran tersebut, dapat dilihat bahwa penyembunyian diri (PD) atau perilaku menutup diri dan harapan pengungkapan (HP) atau ekspektasi untuk membuka diri merupakan variabel penting yang mempengaruhi sikap pencarian bantuan psikologis seseorang, baik layanan tatap muka (offline) maupun daring (online). Selain itu, stigma diri terhadap pencarian bantuan psikologis (SDPB) juga menjadi variabel yang menjadi prediktor signifikan terhadap sikap terhadap pencarian bantuan dan menjadi faktor yang menentukan apakah seseorang akan datang dan terlibat dalam proses psikoterapi (Owen dkk., 20I3; Topkaya, 20I4).

PD, HP, dan SDPB sebagai penghambat perilaku mencari bantuan psikologis telah ditemukan juga pada subjek mahasiswa Korea Selatan, mahasiswa Asia Amerika (Masuda \& Boone, 20II), Amerika Latin (Mendoza dkk., 20I6), dan Turki (Topkaya, 20I4). Hal ini mungkin terjadi karena kesamaan nilai budaya di mana pada budaya timur dan latin menunjukkan pengungkapan diri yang berkonten negatif dan bersifat berlebihan berlawanan dengan budaya kolektif mereka. Permasalahan ini juga tampaknya terjadi di Indonesia, tapi belum banyak ditemukan penelitian terkait faktor-faktor penghambat seseorang mencari bantuan psikologis pada masyarakat Indonesia. Oleh karena itu penelitian ini bertujuan untuk melihat bagaimana PD, HP, dan SDPB pada mahasiswa di Semarang dengan budaya Jawa dan keagamaan yang kental serta bagaimana ketiga variabel tersebut mempengaruhi sikap terhadap pencarian bantuan psikologis. Persepsi terhadap pencarian bantuan psikologis daring ditambahkan mengingat munculnya beberapa platform konseling daring di Indonesia. Penelitian di Korea Selatan menunjukkan bahwa mahasiswa menunjukkan sikap yang lebih positif terhadap konseling daring dibandingkan tatap muka (Bathje dkk., 20l4).

Variabel sikap terhadap mencari layanan psikologi profesional diperkenalkan pada tahun 1970 oleh Fischer dan Turner, yang terdiri atas (a) persepsi pengakuan kebutuhan akan bantuan psikologis profesional, (b) toleransi terhadap stigma yang berhubungan dengan pencarian bantuan psikologis, (c) keterbukaan seseorang terkait permasalahan yang dialami, (d) kepercayaan terhadap kemampuan layanan psikologi profesional untuk memberikan bantuan (Mackenzie dkk., 20 I4). Sikap terhadap pencarian bantuan psikologis dipilih karena menurut Theory of Planned Behavior (Ajzen, 20 I2) menyatakan bahwa seseorang akan mengembangkan niatan spesifik yang akan mempengaruhi 
perilakunya di masa yang akan datang. Teori ini menyarankan bahwa sikap terhadap suatu perilaku adalah satu variabel yang dapat dimanipulasi untuk mempengaruhi niatan perilaku, yang pada akhirnya akan mempengaruhi perilaku.

Penelitian terkait konseling online di luar negeri mendapat banyak perhatian dan penerimaan sebagai salah satu metode konseling. Psikolog yang memiliki keahlian dalam bidang teknologi seringkali menggunakan media online dan bahkan melakukan praktik psikologi secara online. Di Indonesia sendiri telah terdapat beberapa platform konseling online yang telah cukup banyak digunakan oleh klien, seperti pijarpsikologi.org, aplikasi Riliv, Kariib, Lift Up, dan lain sebagainya. Hasil penelitian di Korea Selatan menunjukkan bahwa konseling online menumbuhkan sikap yang lebih positif terhadap bantuan psikologis dibandingkan tatap muka (Bathje dkk., 20 I4). Namun belum banyak penelitian terkait dengan kegunaan platform konsultasi online tersebut di Indonesia. Menurut reviu sistematis yang dilakukan oleh Dowling \& Rickwood (20I3) konseling online (terutama dalam hal ini chat) dapat menjadi metode yang menjanjikan meski masih diperlukan penelitian lanjutan yang ekstensif.

Self-concealment atau Penyembunyian Diri (PD) pertama kali diperkenalkan oleh D.G.Larson dan Chastain pada tahun 1990. Penyembunyian Diri didefinisikan sebagai kecenderungan untuk menutupi informasi pribadi yang dianggap negatif atau membuat hendaya dan ditemukan berhubungan dengan sikap terhadap konseling. Informasi pribadi yang disembunyikan ini bersifat a) bagian dari informasi sangat pribadi yang dimiliki individu, b) secara sadar mudah diakses oleh individu, dan c) secara aktif disimpan dari orang lain (Larson dkk., 20I5). Hasil penelitian mereka pada tahun 1990 menunjukan bahwa terdapat hubungan yang signifikan antara tingginya tingkat PD seseorang dengan tingkat gejala fisik dan psikologis yang ia alami. Hal ini terjadi karena PD menghambat perilaku seseorang untuk mengungkapkan pengalaman negatif mereka, sehingga pilihan coping untuk memecahkan masalah juga terhambat, dan orang-orang terdekat juga tidak bisa menawarkan bantuan (Larson dkk., 20 I 5). Dari hasil penelitian tersebut kita bisa melihat bahwa PD berpengaruh secara langsung terhadap sikap negatif terhadap pencarian bantuan.

PD merupakan salah satu variabel yang paling banyak diteliti dan dianggap paling memberikan kontribusi dalam perilaku pencarian bantuan terutama pada orang Asia, Amerika Latin, dan Afrika karena terkait dengan nilai budaya mereka. Hal ini terjadi karena pada orang Asia kemampuan mengontrol emosi dan menjaga reputasi baik diri sendiri maupun reputasi adalah hal yang sangat dihargai, sehingga pengungkapan diri dan ekspresi emosi yang kuat dianggap tidak sesuai karena berlawanan dengan keharmonisan kolektif baik pribadi maupun keluarga (Kakhnovets, 20 I I). Hasil penelitian menunjukkan secara umum PD berkontribusi terhadap sikap terhadap bantuan psikologis pada mahasiswa Asia Amerika, Latin Amerika, Afrika Amerika, dan Eropa Amerika di mana PD berhubungan dengan kepercayaan terhadap praktisi kesehatan mental (Masuda \& Boone, 20 I I) dan toleransi terhadap stigma serta keterbukaan interpersonal (Mendoza dkk., 20I5).

Selain PD, faktor lain yang dianggap juga berkontribusi terhadap sikap terhadap pencarian bantuan psikologis adalah Disclosure Expectation atau Harapan Pengungkapan (HP). Hal ini ditunjukkan oleh meta analisis yang dilakukan oleh Nam, dkk (20l3), di mana di antara berbagai faktor yang ada, ditemukan bahwa stigma diri, keuntungan yang diharapkan, dan pengungkapan diri memiliki effect size terbesar terhadap sikap terhadap bantuan psikologis. Beberapa penelitian lain juga mendukung hal ini yaitu pada mahasiswa di Iran menunjukkan bahwa persepsi terhadap risiko negatif yang akan terjadi setelah mengungkapkan informasi pribadi berpengaruh secara negatif dan signifikan terhadap sikap terhadap pencarian bantuan psikologis (Kuok \& Rashidnia, 2019).

Dalam kaitannya dengan HP, terdapat Disclosure Decision Model atau Model Keputusan Pengungkapan yang dicetuskan dan dikembangkan oleh Greene, dkk. (20I I) untuk secara spesifik menjelaskan perilaku pengungkapan yang terkait dengan kesehatan. Model ini menyatakan bahwa keputusan untuk mengungkapkan diri melibatkan tiga hal ini yaitu: penilaian informasi, asesmen penerima informasi, dan efikasi pengungkapan. Individu akan melakukan penilaian terhadap aspek informasi yang akan diungkapkan dan jika ia memutuskan bahwa dampak positif dari mengungkapkan informasi tersebut lebih besar daripada risikonya, maka ia akan mempertimbangkan mengungkapkan informasi tersebut. Sebagai tambahan, individu akan mempertimbangkan potensi penerima informasi dengan menilai kualitas hubungannya dengan penerima dan respon yang sekiranya akan didapatkan. Terakhir, individu juga menilai kemampuannya dalam mengungkapkan informasi tersebut. Lebih 
lanjut, model ini memprediksi bahwa jika efikasi pengungkapkan meningkat, maka individu tersebut akan lebih mungkin melakukan pengungkapan diri lagi di masa yang akan datang. Tahap terakhir dari proses pembuatan keputusan ini adalah memilih setting, waktu, cara, dan pesan.

Seperti telah dipaparkan sebelumnya, faktor yang juga dianggap berkontribusi terhadap sikap terhadap pencarian bantuan psikologis adalah stigma diri (SD), yaitu menurunnya harga diri individu karena ia melabel dirinya sebagai seseorang yang secara sosial tidak bisa diterima (Corrigan \& Rao, 20 I2). Hasil penelitian menunjukkan bahwa stigma diri ini berkontribusi terhadap sikap terhadap bantuan psikologis, yaitu responden dengan stigma diri yang lebih tinggi menganggap layanan yang diberikan oleh dokter umum atau psikiater kurang penting (Pattyn dkk., 20 I4) dan secara umum berkontribusi terhadap rendahnya sikap terhadap pencarian bantuan psikologis (Cheng dkk., 20 I3; Tucker dkk., 20I3). Hasil meta analisis yang dilakukan oleh Clement, dkk., (20I5) menunjukkan bahwa stigma yang terinternalisasi dan terkait dengan penanganan merupakan jenis stigma yangpaling berhubungan dengan sikap terhadap pencarian bantuan psikologis dan stigma memiliki effect size kecil hingga sedang terhadap bantuan psikologis. Lebih lanjut, stigma diri juga berpengaruh terhadap self-esteem seseorang, terutama mereka yang mengalami gangguan jiwa sehingga mencari bantuan dianggap sebagai bentuk ketidakmampuan dalam menghadapi masalahnya sendiri (Latalova dkk., 20I4).

Berdasarkan pemaparan di atas, maka penelitian ini bertujuan untuk mengetahui bagaimana hubungan antara PD, HP, dan SDPB terhadap sikap pencarian bantuan psikologis baik tatap muka maupun secara daring pada mahasiswa di Indonesia, khususnya Semarang. Memahami bagaimana ketiga variabel tersebut mempengaruhi sikap pencarian bantuan psikologis sangat penting untuk melihat seberapa besar kontribusi PD, HP, dan SDPB terhadap pencarian bantuan dan mengetahui gambaran tingkat PD, HP, dan SDPB mahasiswa di Indonesia, sehingga nantinya dapat ditemukan cara intervensi yang tepat untuk meningkatkan sikap positif terhadap pencarian bantuan psikologis.

\section{Metode}

Penelitian ini menggunakan pendekatan kuantitatif survei dengan subjek penelitian adalah mahasiswa. Prosedur penelitian ini adalah tahap pertama adaptasi dan uji coba alat ukur, dilanjutkan dengan menentukan sampel penelitian, dan menyebarkan kuesioner penelitian secara tatap muka kepada subjek penelitian. Proses pengambilan data dilakukan selama kurang lebih dua minggu. Langkah terakhir adalah analisis data dan pelaporan.

Subjek penelitian (sampel) adalah mahasiswa Universitas Islam Sultan Agung (UNISSULA) angkatan 2018 (usia I 8-20 tahun) sejumlah 756 orang yang berasal dari I 0 fakultas (kecuali Fakultas Psikologi). Metode sampling yang digunakan cluster sampling, yaitu diketahui jumlah mahasiswa angkatan $2018 \mathrm{di}$ Unissula adalah 2904 orang, lalu dilihat jumlahnya pada masing-masing fakultas, dan diambil sekitar $27 \%$ dari total jumlah mahasiswa yang ada pada setiap fakultas.

Dari proses pengambilan data didapatkan subjek perempuan sebesar $69,3 \%$ dan laki-laki sebesar 3 I,7\% dengan sebagian besar subjek berusia I5-20 tahun (95,7\%). Berikut adalah data demografi subjek penelitian: 
Tabel I. Data Demografi Subjek

\begin{tabular}{llc}
\hline & \multicolumn{1}{c}{ Keterangan } & Jumlah \\
\hline Jenis kelamin & Laki-laki & 232 \\
& Perempuan & 524 \\
\hline Usia & & \\
& $15-20$ & 724 \\
& $21-25$ & 32 \\
\hline Tempat tinggal & & \\
& Tidak menyebutkan & 10 \\
& Asrama & 24 \\
& Kontrak & 40 \\
& Kos & 415 \\
& Pesantren & 7 \\
& Rumah sendiri (dengan orangtua) & 226 \\
& Lainnya & 34 \\
\hline Asal Fakultas & & 197 \\
& Fakultas Ekonomi & 40 \\
& Fakultas Keguruan dan Ilmu Pendidikan & 54 \\
& Fakultas Teknologi Industri & 100 \\
& Fakultas Kedokteran & 59 \\
& Fakultas Ilmu Keperawatan & 27 \\
& Fakultas Kedokteran Gigi & 103 \\
& Fakultas Hukum & 50 \\
& Fakultas Bahasa dan IImu Komunikasi & 49 \\
& Fakultas Agama Islam & 77 \\
\hline & Fakultas Teknik &
\end{tabular}

Instrumen penelitian ada empat yaitu Skala Penyembunyian Diri, Skala Harapan Pengungkapan, Skala Stigma Diri Pencarian Bantuan, dan Skala Sikap terhadap Konseling Daring dan Tatap Muka. Semua instrumen penelitian yang digunakan dalam penelitian ini telah melalui proses adaptasi bahasa dan uji coba dengan prosedur standar adaptasi, yaitu penerjemahan forward dan backward, pilot testing, dan uji coba lapangan pada 192 mahasiswa Fakultas Psikologi Unissula tahun pertama dan kedua. Berikut adalah rincian properti psikometris dari setiap instrumen yang digunakan dalam penelitian ini:

Pertama Self Concealment Scale (Skala Penyembunyian Diri) yang merupakan skala dengan 10 butir yang menggunakan skala Likert 5 jawaban yaitu I (sangat tidak setuju) hingga 5 (sangat setuju) untuk setiap butirnya. Hasil jawaban nantinya akan dijumlahkan dengan nilai yang lebih besar menunjukkan penyembunyian diri yang lebih besar. Skala ini memiliki reliabilitas yang baik yaitu dengan reliabilitas retes dan konsistensi internal 0,8I dan 0,83 (Larson, Chastain, \& Hoyt, 20 I 5). Dalam penelitian ini koefisien reliabilitas Alpha Cronbach 0,855 dengan daya diskriminasi aitem bergerak antara 0,2680,508 .

Kedua, Disclosure Expectation Scale (Skala Harapan Pengungkapan), skala ini terdiri atas 8 butir yang mengukur konsekuensi yang diharapkan terkait pengungkapan informasi personal yang bersifat negatif kepada psikolog/konselor. Skala ini menggunakan jawaban skala Likert dengan 5 pilihan jawaban yaitu I (tidak sama sekali) dan 5 (sangat). Semakin tinggi skor menunjukkan hasil yang positif atas pengungkapan informasi pribadi pada psikolog/konselor. Skala ini terdiri atas dua aspek utama yaitu aspek keuntungan dan risiko yang diantisipasi. Konsistensi internal skala ini adalah 0,74 untuk subskala risiko dan 0,83 untuk subskala keuntungan (Vogel \& Wester, 2003). Dalam penelitian ini reliabilitas alpha Cronbach subskala keuntungan adalah 0,763 dan subskala risiko 0,642.

Ketiga Self-Stigma of Seeking Help Scale (Skala Stigma Diri Pencarian Bantuan) di mana skala ini terdiri atas 10 aitem yang mengukur tingkat kenyamanan atau ketidaknyamanan seseorang untuk mencari bantuan psikologis dari terapis. Skor aitem berkisar antara I -5. Aitem yang dibalik adalah 2, 4, 5, 7, 
dan 9, dengan konsistensi internal adalah 0,9l (Vogel dkk., 2006). Dalam penelitian ini, koefisien reliabilitas Alpha Cronbach 0,624 di mana daya diskriminasi aitem bergerak antara -0,0 I6-0,477. Diketahui aitem nomor 4, 5, dan 9 memiliki daya diskriminasi di bawah 0,3 sehingga tidak diikutkan dalam penghitungan reliabilitas selanjutnya. Dengan tujuh aitem koefisien reliabilitas Alpha Cronbach menjadi 0,725 .

Keempat The Online and Face-to-Face Counseling Attitudes Scales (Skala Sikap terhadap Konseling Daring dan Tatap Muka), skala ini diciptakan oleh (Rochlen dkk., 2004), terdiri atas dua subskala yang mengukur dua aspek utama yaitu aspek value atau nilai kebermanfaatan dan aspek discomfort atau ketidaknyamanan:

a. OCAS (Online Counseling Attitude Scale atau Skala Sikap Konseling Daring), terdiri atas 10 aitem yang mengukur sikap terhadap konseling daring. Setiap aitem memiliki skor antara I (sangat tidak setuju) dan 6 (sangat setuju). Semakin tinggi skor semakin menunjukan sikap yang positif terhadap konseling daring. Koefisien reliabilitas alpha untuk OCAS adalah 0,77-0,88 (Rochlen dkk., 2004). Dalam penelitian ini, OCAS memiliki koefisien reliabilitas 0,676 dengan aitem nomor 6 memiliki daya diskriminasi $-0,38$ I sehingga tidak diikutkan dalam analisis dan koefisien reliabilitas alpha untuk 9 aitem OCAS adalah 0,766. Lebih lanjut subskala nilai kebermanfaatan memiliki koefisien reliabilitas alpha 0,834 dengan daya diskriminasi bergerak antara 0,554-0,705 dan subskala ketidaknyamanan 0,565 dengan daya diskriminasi bergerak antara -0,027-0,564. Diketahui aitem nomor 6 memiliki daya diskriminasi $-0,027$ sehingga tidak diikutkan dalam analisis reliabilitas selanjutnya dan koefisien reliabilitas alpha menjadi $0,68 \mathrm{I}$.

b. F2FCAS (Face to Face Counseling Attitude Scale atau Skala Sikap Konseling Tatap Muka) terdiri atas 10 aitem yang mengukur sikap terhadap terapi tatap muka yang dikembangkan bersamaan dengan OCAS. Aitem F2FCAS sama dengan OCAS hanya istilah "daring" diganti menjadi tatap muka. Skor yang lebih tinggi mencerminkan sikap yang lebih positif terhadap terapi tatap muka. Koefisien reliabilitas aplha untuk F2FCAS adalah 0,77-0,90 (Rochlen dkk., 2004). Dalam penelitian ini, F2FCAS memiliki koefsien reliabilitas alpha 0,784. Diketahui bahwa aitem nomor 16 memiliki daya diskriminasi $-0,198$ sehingga tidak diikutkan dalam analisis dan koefisien reliabilitas alpha menjadi 0,842 . Lebih lanjut pada subskala kebermanfaatan memiliki koefisien reliabilitas alpha 0,876 dengan daya diskriminasi bergerak antara $0 \mathrm{f}, 643-0,763$. Koefisien reliabilitas alpha Cronbach untuk Subskala Ketidaknyamanan adalah 0,733 dengan daya diskriminasi bergerak antara 0,020-0,733. Diketahui aitem nomor 16 yang memiliki daya diskriminasi di bawah 0,020 sehingga tidak diikutkan dalam penghitungan reliabilitas selanjutnya dan hasil penghitungan reliabilitas selanjutnya adalah 0,848 .

Analisis data yang digunakan adalah regresi linear berganda untuk mengetahui apakah prediktor (variabel bebas) dapat memprediksi secara signifikan variabel dependen dan mengetahui sumbangan efektif dari variabel bebas.

\section{Hasil}

Proses pengambilan data dilakukan pada mahasiswa angkatan 2018 (tahun kedua, semester 3) di Universitas Islam Sultan Agung yang berasal dari 10 fakultas yaitu Fakultas Ekonomi, Fakultas Hukum, Fakultas Agama Islam, Fakultas Teknik, Fakultas Teknik Industri, Fakultas Bahasa dan Ilmu Komunikasi, Fakultas Ilmu Keguruan dan Pendidikan, Fakultas Kedokteran Gigi, Fakultas IImu Keperawatan, dan Fakultas Kedokteran. Fakultas Psikologi tidak dijadikan sampel karena terkait dengan variabel penelitian, mahasiswa jurusan psikologi dianggap memiliki literasi kesehatan mental yang lebih tinggi dibandingkan fakultas yang lain sehingga akan mempengaruhi respon jawaban.Jumlah seluruh mahasiswa strata I angkatan 20 I 8 adalah 2904 dan diambil sampel sebanyak 800 mahasiswa (sekitar 27\%). Pengambilan data dilakukan dalam kurun waktu 9-24 September 2019. Dari 800 kuesioner yang disebarkan, kuesioner yang kembali adalah 756. Kondisi ini terjadi karena banyaknya subjek yang tidak mengisi kuesioner secara lengkap dan sungguh-sungguh. 
Deskripsi Data

Tabel 2. Statistik Deskriptif

\begin{tabular}{ccccc}
\hline Variabel & Min & Maks & Rerata & SD \\
\hline PD & 10 & 50 & 31,6 & 7,44 \\
HP & 10 & 40 & 25,8 & 4,42 \\
HP-PR & 4 & 20 & 12,1 & 3,27 \\
HP-PK & 4 & 20 & 13,9 & 3,40 \\
SDPB & 8 & 30 & 18,9 & 3,24 \\
KD & 10 & 45 & 26,8 & 4,99 \\
KTM & 9 & 45 & 29,7 & 5,08 \\
KD-KM & 5 & 25 & 15,2 & 3,98 \\
KTM-KM & 5 & 25 & 17,7 & 3,82 \\
KD-KT & 4 & 20 & 12,4 & 2,93 \\
KTM-KT & 4 & 20 & 12 & 2,93 \\
\hline
\end{tabular}

*PD = Penyembunyian Diri, HP = Harapan Pengungkapan, HP-PR= Harapan Pengungkapan Persepsi Risiko, HP-PK= Harapan Pengungkapan Persepsi Keuntungan, SDPB= Stigma Diri Pencarian Bantuan, KD= Konseling Daring, KTM= Konseling Tatap Muka, KD-KM= Konseling Daring Kebermanfaatan, KTM-KM= Konseling Tatap Muka Kebermanfaatan, KD-KT= Konseling Daring Ketidaknyamanan, KTM-KT= Konseling Tatap Muka Ketidaknyamanan

Lebih lanjut berikut ini adalah hasil analisis regresi ganda untuk mengetahui apakah keempat variabel bebas (HP-PR, HP-PK, SDPB, dan PD) dapat memprediksi secara signifikan sikap terhadap konseling baik secara daring maupun tatap muka.

I. Sikap Terhadap Konseling Daring (KD)

Hasil regresi ganda menunjukkan bahwa model regresi dengan KD sebagai variabel dependen dan HP-PR, HP-PK, PD, dan SDPB sebagai prediktor menunjukkan bahwa model cukup mampu menggambarkan $(F(4,75 I)=I I, 4, P<.00 I)$, meski model hanya mampu menjelaskan 5,7\% sikap terhadap KD. HP-PR $(B=-0,219495 \% \mathrm{Cl}[-0.3364,-0.10242], \mathrm{SE}=$ $0,0596, t=-3,682, p<.00 I), \mathrm{HP}-\mathrm{PK}(B=0,260 I 95 \% \mathrm{Cl}[0,1555,0,36467], \mathrm{SE}=0,0533, \mathrm{t}=4,882$, $p<.00 \mathrm{I})$ dan SDPB $(B=-0, \mathrm{I} I 7 \mathrm{I} 95 \% \mathrm{Cl}[-0,2272,-0,00707], \mathrm{SE}=0,056 \mathrm{I}, \mathrm{t}=-2,089, \mathrm{p}=.037)$ mampu menjelaskan variasi sikap terhadap KD, sementara PD tidak menjadi prediktor signifikan $(p=0,572, p=0,572)$.

Selanjutnya dilakukan analisis regresi ganda dengan KD-KM dan KD-KT sebagai variabel dependen. Pada KD-KM sebagai variabel dependen, didapatkan hasil bahwa model regresi dengan HP-PR, HP-PK, SDPB, dan PD sebagai prediktor cukup mampu menggambarkan $(F(4,75 I)=19,7, P<.00 I)$, di mana model mampu menjelaskan $9,4 \%$ variasi dari KD $-K M$. Dari keempat prediktor, HP-PK menjadi prediktor terkuat $(B=0,335895 \% \mathrm{Cl}[0,254 \mathrm{I}, 0,4 \mathrm{I} 75], \mathrm{SE}=$ $0,04 I 6, t=8,068, p<.00 I)$, diikuti $P D(B=0.056395 \% \mathrm{Cl}[0.0162,0.0963], S E=0.0204, t=2.758$, $p=0.006)$, sementara HP-PR $(p=0.273, p>0.05)$ dan SDPB tidak menjadi prediktor signifikan $(p=0,723, p>0.05)$.

Pada KD-KT sebagai variabel dependen hasil analisis regresi ganda menunjukkan bahwa model cukup dapat menggambarkan $(F(4,75 \mathrm{I})=23,8, \mathrm{p}<.00 \mathrm{I})$, model mampu menjelaskan II,3\% variasi dari KD-KT. Semua variabel bebas menjadi prediktor yang signifikan dengan HP-PR menjadi prediktor terkuat $(B=0,168395 \% \mathrm{Cl}[0,1043,0,2323], S E=0,0326, t=5, I 6, p<.00 I)$, diikuti dengan SDPB $(B=0,132695 \% \mathrm{Cl}[0,0724,0,1928], S E=0,0307, t=4,32, p<.001), H P-P K$ $(B=0.075795 \% \mathrm{Cl}[0.0185,0.1329], S E=0.0292, t=2.60, p=0.010)$, dan $P D(B=0.04 I 595 \%$ $\mathrm{Cl}[0.0135,0.0696], \mathrm{SE}=0.0143, \mathrm{t}=2.9 \mathrm{I}, \mathrm{p}=0.004)$.

2. Sikap Terhadap Konseling Tatap Muka (KTM)

Hasil analisis regresi ganda dengan KTM sebagai variabel dependen dan HP-PR, HP-PK, $P D$, dan SDPB sebagai prediktor menunjukkan bahwa model mampu menjelaskan $(F(4,750)=$ 
40,7, $\mathrm{P}<.00$ I). Model ini mampu menjelaskan I7,8\% variasi sikap terhadap KTM, di mana HP-PK menjadi prediktor terkuat $(B=0,470595 \% \mathrm{Cl}[0,37 \mathrm{I} 0,0,5699], S E=0,0507, t=9,284, p<.00 I)$, diikuti HP-PR ( $B=-0,28 I 395 \% \mathrm{Cl}[-0,3925,-0,17000], S E=0,0567, t=-4,963, p<.00 I)$, dan SDPB $(B=-0,271795 \% \mathrm{Cl}[-0,3764,-0,1670], S E=0,0248, t=-5,904, p<.00 I)$, sementara PD tidak menjadi prediktor signifikan terhadap KTM $(p=0,34 \mathrm{I}, \mathrm{p}>0.05)$.

Selanjutnya dilakukan analisis regresi ganda dengan KTM-KM dan KTM-KT sebagai variabel dependen. Pada KTM-KM sebagai variabel dependen, hasil analisis regresi ganda menunjukkan bahwa model dapat diterima dengan $F(4,750)=47,3, \mathrm{P}<.00 \mathrm{I}$, model dapat menjelaskan 20,1\% variasi dari KTM-KM. Dari empat prediktor yang ada, HP-PK menjadi prediktor terkuat $(B=0,464895 \% \mathrm{Cl}[0,39096,0,5386], S E=0,0376, t=12,36, p<.00 I)$ diikuti $\operatorname{SDBP}(B=-0, \mathrm{I} 30795 \% \mathrm{Cl}[-0,20836,-0,0530], S E=0,0396, t=-3,30, p<.0 \mathrm{I})$ sementaraPD $(p=$ $0.100, p>0.05)$ dan HP-PR $(p=0.097, p>0.05)$ tidak menjadi prediktor signifikan.

Pada KTM-KT sebagai variabel dependen didapatkan hasil regresi ganda bahwa model dapat diterima dengan $\mathrm{F}(4,75 \mathrm{I})=30, \mathrm{I}, \mathrm{P}<.00 \mathrm{I}$ dan mampu menjelaskan I3,8\% variasi dariKTM$\mathrm{KT}$. Di antara empat prediktor yang ada, HP-PR menjadi prediktor terkuat $(B=0,2 \mathrm{I} \mid 4695 \% \mathrm{Cl}$ $[0, \mid 457,0,2772], S E=0,0335, t=6,3 \mid 4, p<.00 I)$, diikuti SDPB $(B=0, I 405895 \% \mathrm{Cl}[0,0790$, $0,2027], \mathrm{SE}=0, \mathrm{I} 4085, \mathrm{t}=4,472, \mathrm{P}<.00 \mathrm{I})$ dan $\mathrm{PD}(\mathrm{B}=0,0540395 \% \mathrm{Cl}[0,0252,0,0828], \mathrm{SE}=$ $0,0147, t=3,68 I, P<.00 I)$ sedangkan HP-PK tidak menjadi prediktor signifikan $(P=0,847$, $\mathrm{P}>0,05)$.

Dari analisis regresi ganda di atas, semua residualnya membentuk distribusi normal dan dihasilkan varians yang homogen. Selain itu, juga dilakukan diagnosis outliers dengan Cook's Distance yang hasilnya menunjukkan bahwa jika outliers tidak dimasukkan dalam analisis datamaka rerata, median, dan SD kurang dari satu nilai awalnya sehingga tidak mendistorsi garis regresi.

Selanjutnya dilakukan analisis tambahan yaitu pertama perbedaan sikap terhadap KDdan KTM, di mana rerata KD adalah 26,8 dan KTM adalah 29,7 dengan perbedaan rerata - I I,3, P $<.00 \mathrm{I}$, yang berarti terdapat perbedaan sikap terhadap KD dan KTM yang sangat signifikan, di mana sikap terhadap KTM lebih positif dibandingkan KD. Kedua, perbedaan persepsi kebermanfaatan dan ketidaknyamanan konseling daring dan tatap muka ditinjau dari jen is kelamin yang hasilnya menunjukkan tidak ada perbedaan KD dan KD-KM ditinjau dari jenis kelamin sementara terdapat perbedaan signifikan KD-KT ditinjau dari jenis kelamin $(t=-2,025, p<0.05)$, di mana rerata KD-KT pada perempuan $(I 2,5)$ lebih tinggi dibandingkan laki-laki $(I 2, I)$. Selanjutnya pada KTM, KTM-KM, dan KTM-KT tidak ditemukan perbedaan ditinjau dari jenis kelamin. Ketiga, perbedaan PD, HP-PK, HP-PR, dan SDPB ditinjau dari jenis kelamin yang hasilnya menunjukkan ditinjau dari jenis kelamin tidak ada perbedaan PD $(p>0,05)$ dan HP-PR, sementara terdapat perbedaan pada HP-PK di mana terdapat perbedaan persepsi keuntungan atas pengungkapan masalah psikologis yang sangat signifikan ditinjau dari jenis kelamin $(t-4,335$, $\mathrm{P}<0,00 \mathrm{I}$ ), di mana perempuan memiliki rerata yang lebih tinggi dibandingkan laki-laki, juga pada SDPB (t 3,195, $p<0,00)$, di mana laki-laki memiliki rerata yang lebih tinggi dibandingkan perempuan.

\section{Pembahasan}

Penelitian ini bertujuan untuk mengetahui kontribusi Penyembunyian Diri, Harapan Pengungkapan, dan Stigma diri terhadap sikap terhadap bantuan psikologis tatap muka dan daring. Hasil analisis Hasil analisis regresi ganda menunjukkan bahwa hipotesis utama yang diajukan dapat diterima, yaitu Penyembunyian Diri, Harapan Pengungkapan-Persepsi Kebermanfaatan, Harapan Pengungkapan-Persepsi Risiko, dan Stigma Diri terhadap Bantuan Psikologis secara bersama-sama dapat memprediksi secara signifikan sikap positif, persepsi kebermanfaatan, dan persepsi ketidaknyamanan terhadap konseling baik secara daring maupun tatap muka. Hasil di atas juga menunjukkan bahwa prediktor signifikan untuk sikap terhadap Konseling Tatap Muka maupun Konseling Daring adalah Harapan Pengungkapan-Persepsi Kebermanfaatan, Harapan PengungkapanPersepsi Risiko, dan Stigma Diri terhadap Bantuan Psikologis sedangkan Penyembunyian Diri tidak menjadi prediktor signifikan untuk sikap terhadap kedua metode konseling. Di sisi lain, Harapan 
Pengungkapan-Persepsi Kebermanfaatan menjadi prediktor terkuat untuk sikap terhadap keduajenis metode konseling. Harapan Pengungkapan-Persepsi Kebermanfaatan juga menjadi prediktor terkuat untuk aspek kebermanfaatan baik konseling daring maupun tatap muka, sedangkan Harapan Pengungkapan-Persepsi Risiko menjadi prediktor terkuat untuk aspek ketidaknyamanan kedua metode konseling tersebut. Secara umum, hasil regresi ganda menunjukkan bahwa keempat variabel independen lebih mampu menjelaskan sikap terhadap Konseling Tatap Muka (dengan sumbangan efektif I 7,8\%) dibandingkan dengan Konseling Daring (5,7\%) yang berarti bahwa banyak variabel lain yang mungkin dapat lebih memprediksi sikap terhadap Konseling Daring. Hal ini juga dapat terjadi karena subjek dalam penelitian ini belum memiliki pengalaman terkait konseling daring, sehingga belum memiliki gambaran menyeluruh terkait metode konseling tersebut.

Dari deskripsi data, dapat dilihat pada Tabel 2 dapat dilihat bahwa rerata sikap positif terhadap Konseling Tatap Muka $(29,7)$ lebih tinggi dibandingkan dengan Konseling Daring $(26,8)$, dengan perbedaan rerata yang sangat signifikan. Hal ini mengindikasikan adanya sikap yang lebih positif terhadap konseling tatap muka dibandingkan konseling daring pada subjek mahasiswa UNISSULA. Ini juga ditemukan oleh Ballesteros \& Hilliard (2016) pada mahasiswa Amerika Latin dan Wong, Bonn, Tam, \& Wong (2018) pada mahasiswa Malaysia yang lebih memilih konseling tatap muka dibandingkan konseling daring, di mana menurut kedua hasil penelitian tersebut hal ini terjadi karena kebanyakan mahasiswa masih belum terbiasa dan belum memiliki pengalaman menggunakan sistem konseling daring. Lebih lanjut, masih dari Tabel 2, dari rerata yang didapatkan dapat dilihat bahwa secara umum subjek penelitian ini memiliki sikap yang cenderung netral ke arah positif baik terhadap konseling daring maupun tatap muka (rerata 26,8 dan 29,7, dengan kisaran skor 0 -45), di mana hasil ini juga ditemukan oleh Bathje, dkk., (20l4) yang juga menunjukkan mahasiswa Korea Selatan memiliki sikap yang cenderung netral hingga sedikit positif terhadap konseling daring.

Berdasarkan hasil analisis data tambahan, dapat dilihat bahwa ditinjau dari jenis kelamin, tidak terdapat perbedaan sikap terhadap Konseling Daring maupun Konseling Tatap Muka, meski terdapat perbedaan signifikan pada aspek ketidaknyamanan Konseling Daring antara laki-laki dan perempuan, di mana rerata perempuan lebih tinggi dibandingkan laki-laki. Lebih lanjut pada Penyembunyian Diri dan Harapan Pengungkapan-Persepsi Risiko tidak terdapat perbedaan berdasarkan jenis kelamin. $\mathrm{Di}$ sisi lain terdapat perbedaan signifikan berdasarkan jenis kelamin pada Harapan PengungkapanPersepsi Keuntungan di mana perempuan memiliki rerata lebih tinggi dibandingkan laki-laki dan pada Stigma Diri rerata laki-laki lebih tinggi dibandingkan perempuan. Hasil ini sedikit berbeda dengan penelitian sebelumnya, yang mana jenis kelamin berhubungan secara signifikan terhadap sikap pencarian bantuan, perempuan ditemukan memiliki sikap yang lebih positif terhadap sikap pencarian bantuan, di sisi lain juga ditemukan bahwa Stigma Diri lebih tinggi pada laki-laki daripada perempuan (Masuda \& Boone, 20II; Topkaya, 20I4).

Hasil penelitian ini secara umum mendukung hasil penelitian terdahulu terkait sikap terhadap pencarian bantuan psikologis, yang mana Stigma Diri menjadi prediktor negatif terhadap Konseling Konseling Daring dan Konseling Daring-Ketidaknyamanan, juga menjadi prediktor negatif pada Konseling Tatap Muka, baik pada kenyamanan maupun ketidaknyamanan (Ballesteros \& Hilliard, 20 I6; Bathje dkk., 20 I 4; Masuda \& Boone, 20 I I). Hal ini juga mendukung hasil penelitian sebelumnya pada etnis dan ras minoritas di mana semakin tinggi stigma diri maka semakin rendah pula sikap positif terhadap pencarian bantuan (Cheng dkk., 20 I3). Namun demikian hasil penelitian ifni sedikit berbeda dengan yang ditemukan oleh Bathje, dkk., (20I4) pada mahasiswa Korea Selatan, di mana ditemukan bahwa stigma diri berhubungan dengan sikap negatif terhadap Konseling Tatap Muka dan tidak berhubungan dengan Konseling Daring. Dalam penelitian ini stigma diri justru menjadi prediktor signifikan pada Konseling Tatap Muka dibandingkan pada Konseling Daring. Hal ini juga ditemukan pada penelitian lain yang menunjukkan bahwa dampak negatif stigma diri terhadap sikap terhadap konseling daring lebih kecil dibandingkan konseling tatap muka (Joyce, 20 I2).

Pada penelitian dengan subjek mahasiswa Asia ditemukan bahwa penyembunyian diri berhubungan secara negatif dengan sikap terhadap konseling daring maupun tatap muka (Bathjedkk, 20I4; Masuda \& Boone, 20II). Berbeda dengan hasil penelitian tersebut, dalam penelitian ini Penyembunyian Diri tidak menjadi prediktor signifikan baik pada Konseling Daring maupun Konseling Tatap Muka. Meskipun demikian, Penyembunyian Diri menjadi prediktor pada aspek ketidaknyamanan pada kedua modalitas konseling (daring dan tatap muka). Penyembunyian Dirilebih 
dapat menjelaskan aspek ketidaknyamanan kedua metode konseling tersebut. Hal ini berarti bahwa semakin tinggi penyembunyian diri seseorang semakin tinggi pula persepsinya atas ketidaknyamanan dalam kedua modalitas konseling. Hal ini juga ditemukan pada hasil penelitian pada mahasiswa Afrika Amerika juga menunjukkan bahwa Penyembunyian Diri tidak menjadi prediktor signifikan bagi sikap mencari bantuan, meski Penyembunyian Diri berhubungan dengan toleransi stigma dan keterbukaan interpersonal (Mendoza dkk., 20I5).

Pada variabel harapan pengungkapan penelitian menunjukkan bahwa pengaruh Harapan Pengungkapan lebih rendah pada Konseling Daring dibandingkan pada Konseling Tatap Muka (Bathje dkk., 20l4). Hal ini juga ditemukan dalam penelitian ini di mana koefisien beta Harapan Pengungkapan-Persepsi Keuntungan dan Harapan Pengungkapan-Persepsi Risiko lebih tinggi pada Konseling Tatap Muka dibandingkan pada Konseling Daring sehingga menunjukkan bahwa Harapan Pengungkapan lebih dapat menjelaskan Konseling Tatap Muka dibandingkan Konseling Daring.Dalam penelitian ini ditemukan bahwa Harapan Pengungkapan-Persepsi Keuntungan menjadi prediktor terkuat sikap positif terhadap Konseling Daring dan Konseling Tatap Muka serta aspek kebermanfaatan, sementara Harapan Pengungkapan-Persepsi Risiko menjadi prediktor aspek ketidaknyamanan kedua metode konseling. Hal ini juga terjadi pada subjek mahasiswa Uni Emirat Arab (UEA) yang menunjukkan bahwa Harapan Pengungkapan atau ekspektasi yang berhubungan dengan mengungkapkan informasi pribadi pada konselor menjadi variabel mediator yang sangat kuat karena pengungkapan diri dianggap sebagai hal yang tabu di UEA, bahkan dianggap sebagai pengkhianatan pada keluarga dan mencerminkan kelemahan pribadi (Heath dkk., 20l6). Pada mahasiswa dengan latar belakang Asia di Amerika Serikat, individu yang kurang terakulturalisasi (dengan budaya Amerika Serikat) akan kurang bersedia untuk mengungkapkan masalahnya (Chen \& Danish, 20 I0). Lebih lanjut menurut hasil meta analisis Nam, dkk. (20 I3) persepsi keuntungan dan pengungkapan diri menjadi dua dari tiga variabel dengan effect size terbesar yang berkontribusi terhadap sikap terhadap pencarian bantuan psikologis.

Keterbatasan dari penelitian ini adalah subjeknya yang merupakan mahasiswa Universitas Islam Sultan Agung Semarang, di mana 99\% nya beragama Islam sehingga kemungkinan sulit digeneralisasikan pada sampel non muslim juga pada sampel mahasiswa lainnya di universitas negeri atau jenis perguruan tinggi lainnya. Selain itu, dari segi demografi penelitian ini tidak mengungkap lebih jauh terkait kondisi sosial ekonomi dan asal daerah subjek (misalnya pedesaan, kota, pinggiran, dII) yang mungkin mempengaruhi hasil yang didapatkan. Penelitian ini juga tidak mengungkap pengalaman konseling sebelumnya baik secara daring maupun tatap muka karena penelitian sebelumnya menyebutkan bahwa pengalaman menggunakan layanan psikologi menjadi prediktoryang juga signifikan terhadap sikap terhadap pencarian bantuan psikologis. Lebih lanjut penelitian ini juga tidak mengungkap familiaritas subjek dengan gadget kaitannya dengan penggunaan konseling daring. Oleh karena itu diharapkan penelitian yang akan datang dapat menggunakan subjek mahasiswa dari jenis perguruan tinggi yang lain dan lebih banyak mengungkap demografi subjek.

Dalam penelitian ini prediktor yang ada lebih dapat menjelaskan Konseling Tatap Muka, maka perlu mencari prediktor lain yang lebih dapat menjelaskan Konseling Daring, misalnya familiaritas dengan gadget dan memberi gambaran lebih jelas mengenai konseling daring agar subjek yang belum pernah mengikuti konseling daring dapat membayangkan lebih detail. Variabel lain yang dapat dijadikan prediktor dalam penelitian lanjutan misalnya stigma dari orang lain terhadap pencarian bantuan (stigma publik), ketakutan akan psikoterapi, ketakutan akan pengungkapan emosional, dan dalam konteks budaya Jawa dan Indonesia dapat juga dimasukkan kelekatan terhadap nilai budaya Jawa dan nilai keagamaan sebagai prediktor terhadap pencarian bantuan.

\section{Kesimpulan}

Dari penelitian di atas dapat dilihat bahwa secara bersama-sama keempat prediktor yaitu Penyembunyian Diri, Stigma Diri Pencarian Bantuan, dan Harapan Pengungkapan mampu memprediksi secara signifikan sikap terhadap konseling baik daring maupun tatap muka, di mana hanya Penyembunyian Diri yang tidak menjadi prediktor signifikan. Prediktor terkuat adalah Harapan Pengungkapan-Persepsi Keuntungan atau persepsi terhadap keuntungan atas pengungkapan masalah 
psikologis diikuti dengan Stigma Diri Pencarian Bantuan yaitu stigma diri terhadap pencarian bantuan. Pada aspek kebermanfaatan konseling daring Harapan Pengungkapan-Persepsi Keuntungan menjadi prediktor terkuat sementara Harapan Pengungkapan-Persepsi Risiko dan Stigma Diri Pencarian Bantuan tidak menjadi prediktor signifikan dan pada konseling tatap muka Harapan PengungkapanPersepsi Keuntungan juga menjadi prediktor terkuat sementara Harapan Pengungkapan-Persepsi Risiko tidak menjadi prediktor signifikan. Pada aspek ketidaknyamanan konseling daring semua variabel menjadi prediktor signifikan, di mana Harapan Pengungkapan-Persepsi Risiko menjadi prediktor terkuat baik konseling daring maupun tatap muka.

Berdasarkan hasil penelitian di atas, terdapat beberapa implikasi praktis dalam kaitannya dengan peningkatan sikap positif mahasiswa terhadap konseling. Pertama, dari hasil penelitian dapat dilihat bahwa HP merupakan prediktor terkuat, yaitu di mana individu akan mengungkapkan masalahnya jika dirasa memberikan lebih banyak keuntungan. Oleh karena itu perlu banyak sosialisasi tentang gambaran konseling atau psikoterapi, bagaimana proses tersebut menguntungkan klien, bagaimana klien akan dibantu oleh psikolog/konselor, peran dan tugas psikolog, dan secara umum apa saja keuntungan yang didapatkan dengan mendapatkan bantuan psikologis. Kedua, terkaitdengan hal tersebut perlu disosialisasikan pula jenis bantuan psikologis dan alternatif bantuan psikologisyang ada. Ketiga, diperlukan juga sosialisasi tentang kapan mengetahui saat yang tepat mencari bantuan, pada kondisi apa saja bantuan psikologis diperlukan. Hal ini penting untuk menurunkan tingkatstigma diri individu, yaitu agar mengetahui bahwa terdapat beberapa jenis masalah tertentu yang tidak perlu diselesaikan sendiri dan bahwa meminta bantuan psikologis bukanlah suatu hal yang tabu.

\section{REFERENSI}

Ajzen, I. (20I2). Theories of social psychology. In P. A. M. Van Lange, A. W. Kruglanski, \& E. T. Higgins (Eds.), The Theory of Planned Behavior (Vol. I, pp. 438-458). Sage Publication.

Ballesteros, J. L., \& Hilliard, R. C. (2016). U.s.-based latina/o college students' attitudes toward online counseling. International Journal for the Advancement of Counselling, 38(4), 269-285. Doi: I 0.1 007/s 10447-016-927I-x

Bathje, G. J., Kim, E., Rau, E., Bassiouny, M. A., \& Kim, T. (20I4). Attitudes toward face-to-face and online counseling: roles of self-concealment, openness to experience, loss of face, stigma, and disclosure expectations among korean college students. International Journal for the Advancement of Counselling, 36(4), 408-422. Doi: I 0.1007/s I 0447-014-9215-2

Bonabi, H., Müller, M., Ajdacic-Gross, V., Eisele, J., Rodgers, S., Seifritz, E., Rössler, W., \& Rüsch, N. (20।6). Mental health literacy, attitudes to help seeking, and perceived need as predictors of mental health service use: A longitudinal study. Journal of Nervous and Mental Disease, 204(4), 32 I-324. Doi: I0.1097/NMD.0000000000000488

Chen, J. C., \& Danish, S. J. (2010). Acculturation, distress disclosure, and emotional selfdisclosure within asian populations. Asian American Journal of Psychology, I (3), 200-2 I I. Doi: I 0.1037/a0020943

Cheng, H.-L., Kwan, K.-L. K., \& Sevig, T. (20I3). Racial and ethnic minority college students' stigma associated with seeking psychological help: Examining psychocultural correlates. In Journal of Counseling Psychology (Vol. 60, Issue I, Pp. 98-I I I). American Psychological Association. Doi: 10.1037/a0031169

Chu, J. P., Hsieh, K. Y., \& Tokars, D. A. (20I I). Help-seeking tendencies in Asian Americans with suicidal ideation and attempts. Asian American Journal of Psychology, 2(I), 25-38.

Doi: $10.1037 / \mathrm{a} 0023326$

Clement, S., Schauman, O., Graham, T., Maggioni, F., Evans-Lacko, S., Bezborodovs, N., Morgan, C., Rüsch, N., Brown, J. S. L., \& Thornicroft, G. (2015). What is the impact of mental health related stigma on help-seeking? A systematic review of quantitative and qualitative studies. Psychological Medicine, 45(I), I I-27. Doi: I 0.10 I7/S003329I7 I4000I 29

Corrigan, P., \& Rao, D. (20I2). On the self-stigma of mental illness: stages, disclosure, and strategies for change. Canadian Journal of Psychiatry, 57(8), 464-469.

Doi: $10.7748 / n s .24 .19 .64 .557$

Dowling, M., \& Rickwood, D. (2013). Online counseling and therapy for mental health problems : a systematic review of individual synchronous interventions using chat online counseling and 
therapy for mental health problems : a systematic. Journal of Technology in Human Services, 3 I ( I), I-2 I. Doi: I 0.I 080/I5228835.20 I2.728508

Greene, K., Magsamen-Conrad, K., Venetis, M. K., Checton, M. G., Bagdasarov, Z., \& Banerjee, S.

C. $(20 \mathrm{II})$. Assessing health diagnosis disclosure decisions in relationships : testing the disclosure decision-making model assessing health diagnosis disclosure decisions in relationships : testing the disclosure decision-making model. Health Communication, 27(4), 356-368. Doi: I 0.1080/I 0410236.2011 .586988

Griffith, D. M., Allen, J. O., \& Gunter, K. (20I I). Social and cultural factors influence African American men's medical help seeking. Research on Social Work Practice, 2 I (3), 337-347. Doi: 10.1 I 77/104973/510388669

Heath, P. J., Vogel, D. L., \& Al-darmaki, F. R. (20I6). Help-seeking attitudes of united arab emirates students : examining loss of face, stigma, and self-disclosure. The Counseling Psychologist, 44(3), 33 I-352. Doi: I 0.I I77/00 I I0000 I562II 49

Johnson, E. M., \& Coles, M. E. (20I3). Failure and delay in treatment-seeking across anxiety disorders. Community Mental Health Journal, 49(6), 668-674. Doi:I 0.I 007/s I0597-0I 2-9543-9

Joyce, N. (20I2). An empirical examination of the influence of personality, gender role, and self stigma on attitudes and intentions to seek online counseling in college students. University of Akron.

Kakhnovets, R. (20I I). Relationships among personality, expectations about counseling, and help seeking attitudes. Journal of Counseling and Development, 89(I), I I-I 9. Doi:I 0.1 002/j.I 5566678.20I I.tb00056.x

Kuok, A. C. H., \& Rashidnia, J. (2019). College students ' attitudes toward counseling for mental health issues in two developing asian countries. Spiritual Psychology and Counseling, 4, 67-84. Doi:I 0.12738/spc.2019.4.1.0056

Larson, D., Chastain, R., \& Hoyt, W. (20I5). Self-concealment : integrative review and working model. Journal of Social and Clinical Psychology, 34(8), 705-774. Doi: I 0.I 52I/jscp.20I 5.34.8.705

Latalova, K., Kamaradova, D., \& Prasko, J. (20I4). Perspectives on perceived stigma and self-stigma in adult male patients with depression. Neuropsychiatric Disease and Treatment, 10, 1399 | 405. Doi: 0.2 I 47/NDT.S5408 |

Mackenzie, C. S., Erickson, J., Deane, F. P., \& Wright, M. (20I4). Changes in attitudes toward seeking mental health services: A 40-year cross-temporal meta-analysis. Clinical Psychology Review, 34(2), 99-106. Doi:I0.1016/j.cpr.2013.12.001

Masuda, A., \& Boone, M. S. (20I I). Mental health stigma, self-concealment, and help-seeking attitudes among Asian American and European American college students with no helpseeking experience. International Journal for the Advancement of Counselling, 33(4), 266-279. Doi: I 0.1007/s 10447-0I I-9129-I

Mendoza, H., Goodnight, B. L., Caporino, N. E., \& Masuda, A. (2016). Psychological distress among Latina/o college students: the roles of self-concealment and psychological inflexibility. Current Psychology, I, I-8. Doi: I 0.1007/s I2 | 44-01 6-9500-9

Mendoza, H., Masuda, A., \& Swartout, K. M. (20I5). Mental health stigma and self-concealment as predictors of help-seeking attitudes among Latina / o college students in the United States. International Journal of Advance Counselling, 37, 207-222. Doi:I 0. I 007/s I 0447-0I 5-9237-4

Nam, S. K., Choi, S. I., Lee, J. H., Lee, M. K., Kim, A. R., \& Lee, S. M. (20I3). Psychological factors in college students' attitudes toward seeking professional psychological help: A meta-analysis. Professional Psychology: Research and Practice, 44(I), 37-45. Doi: I 0.I $037 / a 0029562$

Novianty, A., \& Retnowati, S. (20 I 6). Intervensi psikologi di layanan kesehatan primer. Buletin Psikologi, 24(I), 48-62. Doi:I 0.22I46/bpsi. 12679

Owen, J., Thomas, L., \& Rodolfa, E. (2013). Stigma for Seeking Therapy. The Counseling Psychologist, 4I (6), 857-880. Doi:I 0.I I77/00 I I0000 I2459365

Pattyn, E., Verhaeghe, M., Sercu, C., \& Bracke, P. (20I4). Public stigma and self-stigma: Differential association with attitudes toward formal and informal help seeking. Psychiatric Services, 65(2), 232-238. Doi: I 0.I I 76/appi.ps.20 I20056 I

Rochlen, A. B., Beretvas, S. N., \& Zack, J. S. (2004). The online and face-to-face counseling attitudes scales: a validation study. Measurement and Evaluation in Counseling and Development, 37(2), 95-I I I. Doi: I 0.I 080/0748I756.2004.I I 909753 
Syafitri, D. U. (20 18). Literasi Kesehatan Mental Mahasiswa di Kota Semarang. Semarang: Fakultas Psikologi Universitas Islam Sultan Agung

Syafitri, D. U., \& Wijayanti, N. (2017). Pentingnya literasi kesehatan mental sebagai upaya peningkatan kualitas hidup masyarakat. Seminar Nasional BAPPEDA: Inovasi Dan Kreasi Memajukan Jawa Tengah, I087-1095.

Topkaya, N. (20 I4). Gender, self-stigma, and public stigma in predicting attitudes toward psychological help-seeking. Educational Sciences: Theory \& Practices, I 4(2), 480-487. Doi:10.1 2738/estp.2014.2.1799

Tucker, J. R., Hammer, J. H., Vogel, D. L., Bitman, R. L., Wade, N. G., \& Maier, E. J. (20I3). Disentangling self-stigma: are mental illness and help-seeking self-stigmas different. Journal of Counseling Psychology, 60 (4), 520-53I. Doi: I 0.I 037/a0033555

Vogel, D. L., Wade, N. G., \& Haake, S. (2006). Measuring the self-stigma associated with seeking psychological help. Journal of Counseling Psychology, 53(3), 325-337. Doi: I 0.1 037/00220167.53 .3 .325

Vogel, D., \& Wester, S. (2003). To seek help or not to seek help: the risks of self-disclosure. In Journal of Counseling Psychology (Vol. 50). Doi: I 0.1 037/0022-0I 67.50.3.35 I

Wong, K. P., Bonn, G., Tam, C. L., \& Wong, C. P. (2018). Preferences for online and/or face-toface counseling among university students in Malaysia. Perspective, 9(64), I-5.

Doi: I 0.3389/fpsyg.2018.00064 